\title{
Efek Suplementasi Daun Ubi Kayu terhadap Kecernaan Daun Sawit Amoniasi secara In Vitro
}

\author{
The Effect of Cassava Leaves Supplementation \\ on Ammoniated Palm Oil Leaves Digestibility In vitro \\ Nurhaita $^{1)}$ dan R.W.S. Ningrat ${ }^{2}$ \\ ${ }^{1)}$ Fakultas Pertanian Universitas Muhammadiyah Bengkulu \\ Jl. Raya Kandang Limun, Bengkulu 38371 \\ ${ }^{2)}$ Fakultas Peternakan Universitas Andalas \\ Kampus Unand Limau Manis, Padang 25163 \\ E-mail:nurhaita@gmail.com
}

(Diterima: 14 Oktober 2010; Disetujui:27 Januari 2011)

\begin{abstract}
The purpose of this study was to obtain the level of supplementation of cassava leaves as a source of branched chain amino acids in improving nutrients digestibility of ammoniation palm leaf, and characteristics of rumen fluid (in-vitro). The experiment was designed by using randomized block design with 6 treatments of supplementation of cassava leaf $(A=0 \%$ as control, $B=5 \%, C=10 \%, D=15 \%, E=$ $20 \%$ and $F=25 \%$ of dry matter) with 4 replications. Parameters were: 1 ) Digestibility of nutrients (dry matter, organic matter, crude protein) 2) Digestibility of fiber fractions (NDF, ADF, cellulose and hemicellulose) and 3) Characteristics of rumen fluid ( $\mathrm{pH}, \mathrm{NH} 3$, and VFA) by in-vitro. The results showed cassava leaves supplementation significantly $(P<0.05)$ increased the in-vitro digestibility of palm leaves ammoniation. The highest dry matter digestibility obtained at cassava leaf $5 \%(24.09 \%)$ in comparing controls $(45.49 \% v s .56 .45 \%)$, and ADF digestibility increased by $36.91 \%$ compared to controls $37.25 \% v s$. $51.00 \%)$. Cassava leaves maintained rumen fluid characteristics for microbial rumen growth and activities. It concluded, the level of supplementation cassava leaves as a source of the best branched chain amino acids in palm leaf ammoniation was $5 \%$.
\end{abstract}

Keywords : Palmoil leaves, cassava leaves, ammoniation, in-vitro digestibility,

\section{PENDAHULUAN}

Daun sawit merupakan limbah perkebunan kelapa sawit yang produksinya sangat melimpah dan potensial dijadikan pakan alternatif pengganti hijauan bagi ternak ruminansia, namun pemanfaatannya sebagai pakan ternak masih sangat terbatas. Hal ini antara lain disebabkan rendahnya kualitas biologis daun sawit. Menurut Djajanegara et al. (1999) kandungan lignin daun kelapa sawit cukup tinggi yaitu $13,79 \%$, sehingga ini menyebabkan rendahnya kecernaan pada daun sawit. Untuk dapat dimanfaatkan secara optimal sebagai sumber pakan hijauan,daun sawit harus diolah terlebih dahulu untuk meningkatkan nilai gizi dan kecernaannya. Teknik pengolahan secara amoniasi terbukti mampu meningkatkan kecernaan daun sawit sebesar $13,10 \%$ dari $32,52 \%$ menjadi $36,78 \%$, namun peningkatan kecernaan ini sangat kecil dan belum memberikan hasil yang optimal untuk mendukung produktifitas ternak (Nurhaita et al., 2007). Karena itu untuk peningkatan kecernaan pakan serat selain upaya pengolahan juga harus dipadukan dengan upaya mengoptimalkan bioproses di dalam rumen melalui peningkatan populasi mikroba rumen karena kecernaan pakan serat dalam rumen sangat tergantung pada kerja enzim yang dihasilkan oleh mikroba.

Pertumbuhan mikroba yang optimal memerlukan ketersediaan nutrient yang cukup seperti nitrogen, asam-asam amino, mineral dan vitamin. Mineral Sulfur dan Pospor merupakan mineral yang esensial bagi mikroba pencerna serat. Suplementasi mineral S dan P pada daun sawit amoniasi mampu meningkatkan kecernaan daun sawit amoniasi sebesar $36,68 \%$ dari $34,67 \%$ menjadi 47,39\% (Nurhaita et al., 2008).

Selain mineral, bakteri selulolitik rumen juga membutuhkan asam lemak rantai bercabang (Branched-Chain fatty acids $=\mathrm{BCFA}$ ) yang terdiri 
dari asam isobutirat, 2 metil butirat dan asam valerat. BCFA ini adalah sumber rangka karbon bagi bakteri yang merupakan hasil dekarboksilasi dan deaminasi dari asam amino rantai bercabang (AARC). AARC dalam rumen sebagian besar berasal dari hasil fermentasi protein ransum dan mikroba rumen yang mengalami lisis. Pada bahan limbah yang berkualitas rendah seperti daun sawit pasokan AARC sangat rendah sehingga diperlukan suplementasi AARC dalam ransum. Penambahan AARC yaitu valin, isoleusin dan leusin mampu meningkatkan populasi mikroba rumen dan kecernaan serat sawit (Zain, 1999).

Sumber AARC alami yang murah dan mudah diperoleh adalah daun ubi kayu. Daun ubi kayu mengandung protein kasar cukup tinggi dengan kandungan asam amino iso leusin $6,70 \mathrm{~g} / 16 \mathrm{~g} \mathrm{~N}$, leusin $10,90 \mathrm{~g} / 16 \mathrm{~g} \mathrm{~N}$ dan valin $5,45 \mathrm{~g} / 16 \mathrm{~g} \mathrm{~N}$ (Devendra, 1979 dalam Muhtaruddin, 2002). Bakrie et al., (1995) melaporkan bahwa kandungan protein kasar daun ubi kayu adalah $19,60 \%$ dan akan meningkat menjadi $25,60 \%$ bila difermentasi dengan Aspergillus niger. Suplementasi daun ubi kayu pada daun sawit amoniasi yang telah disuplementasi dengan mineral $\mathrm{S}$ dan $\mathrm{P}$ terlebih dahulu, diharapkan mampu lebih meningkatkan angka kecernaan sehingga dapat menunjang produktifitas ternak.

\section{MATERI DAN METODE}

Materi penelitian ini adalah daun sawit amoniasi, belerang sebagai sumber mineral sulfur, pupuk TSP sebagai sumber mineral phospor dan tepung daun ubi kayu sebagai sumber asam amino rantai bercabang, larutan Mc Dougall's sebagai buffer dan cairan rumen sebagai donor mikroba. Alat yang digunakan adalah: perangkat in-vitro, $\mathrm{pH}$ meter digital untuk mengukur $\mathrm{pH}$ cairan rumen, dan seperangkat peralatan laboratorium untuk analisis Proksimat, Van Soest, VFA, dan $\mathrm{NH}_{3}-\mathrm{N}$.

Penelitian menggunakan rancangan acak kelompok dengan 6 perlakuan dan 4 ulangan. Perlakuan terdiri dari : $\mathrm{A}=0 \%$ tepung daun ubi kayu sebagai kontrol, $\mathrm{B}=5 \%, \mathrm{C}=10 \%, \mathrm{D}=15 \%$, $\mathrm{E}=20 \%$ dan $\mathrm{F}=25 \%$ tepung daun ubi kayu. Penelitian dilakukan secara in-vitro menurut prosedur Tilley and Terry (1963). Sebelum digunakan sampel daun sawit amoniasi terlebih dahulu dikeringkan dan digiling halus, begitu juga belerang dan TSP dan daun ubi kayu. Sampel dimasukkan ke dalam erlenmeyer lalu tambahkan $0,4 \%$ mineral S dan $0,27 \% \mathrm{P}$, aduk rata mineral dan sampel, kemudian tambahkan tepung daun ubi kayu sesuai dengan perlakuan dan diaduk rata. Selanjutnya diberi larutan buffer Mc. Dougall's dan cairan rumen, gas $\mathrm{CO}_{2}$ dialirkan 30 detik agar kondisi tetap an aerob, lalu mulut tabung ditutup rapat. Sampel dinkubasi selama 2 × 24 jam dalam shaker water bath. Setelah fermentasi berakhir semua sampel disentrifus dengan kecepatan 1200 rpm selama 15 menit untuk memisahkan filtrat dan endapan. Kemudian di lakukan pengukuran karakteristik cairan rumen $\left(\mathrm{pH}, \mathrm{NH}_{3}-\mathrm{N}\right.$ dan VFA) pada filtrat yang di peroleh dan endapan (residu hasil fermentasi in-vitro) dikeringkan untuk dianalisis kandungan zat makanan (BK,BO dan $\mathrm{PK}$ ) dan fraksi seratnya (NDF, ADF, selulosa dan hemiselulosa).

Peubah yang diamati adalah kecernaan bahan kering, bahan organik, protein kasar secara invitro dan kecernaan fraksi serat (NDF, $\mathrm{ADF}$, selulosa dan hemiselulosa), karakteristik cairan rumen $\left(\mathrm{pH}\right.$, kadar VFA dan kadar $\mathrm{NH}_{3}-\mathrm{N}$ cairan rumen). Data yang diperoleh dianalisis dengan menggunakan analisis varian (anova) menurut Steel \& Torrie (1989). Perbedaan antar perlakuan akan diuji dengan Duncan's Multiple Range Test (DMRT).

\section{HASIL DAN PEMBAHASAN}

\section{Kecernaan zat makanan dan fraksi serat}

Dari suplementasi tepung daun ubi kayu pada daun sawit amoniasi yang sebelumnya telah disuplementasi dengan $0,4 \%$ sulfur dan $0,27 \%$ phospor diperoleh angka kecernaan zat-zat makanan seperti terlihat pada Tabel 1. Hasil analisis ragam menunjukkan perlakuan suplementasi beberapa level tepung daun ubi kayu nyata $(\mathrm{P}<0,05)$ mempengaruhi kecernaan zat makanan.

Dari Tabel 1 terlihat bahwa suplementasi tepung daun ubi kayu dapat meningkatkan kecernaan zat makanan. Kecernaan tertinggi diperoleh pada suplementasi $5 \%$ tepung daun ubi kayu,tetapi peningkatan level tepung daun ubi kayu menyebabkan peningkatan angka kecernaan yang semakin menurun, bahkan pada level $20 \%$ dan $25 \%$ nilai kecernaannya sama dengan kontrol. Hal ini disebabkan karena peningkatan jumlah asam amino rantai cabang yang merupakan sumber kerangka karbon untuk sintesis mikroba rumen tidak diikuti dengan ketersediaan energi yang mencukupi untuk sintesis protein mikroba seperti terlihat pada produksi VFA (Tabel 2), sehingga rangka karbon yang tersedia menjadi tidak termanfaatkan. Hal ini membuktikan bahwa 
Tabel 1.Efek suplamentasi beberapa level tepung daun ubi kayu terhadap kecernaan zat-zat makanan daun sawit amoniasi secara in-vitro

\begin{tabular}{|c|c|c|c|c|c|c|c|}
\hline \multirow{2}{*}{$\begin{array}{c}\text { Kecernaan } \\
(\%)\end{array}$} & \multicolumn{6}{|c|}{ Suplementasi Tepung Daun Ubi Kayu (\%) } & \multirow[t]{2}{*}{ SE } \\
\hline & 0 & 5 & 10 & 15 & 20 & 25 & \\
\hline Bahan Kering & $45,492^{c}$ & $56,451^{a}$ & $51,730^{b}$ & $50,295^{b}$ & $48,484^{\mathrm{bc}}$ & $46,450^{c}$ & 1,009 \\
\hline Bahan Organik & $51,286^{\mathrm{c}}$ & $60,881^{\mathrm{a}}$ & $56,787^{a b}$ & $55,068^{b}$ & $53,039^{b c}$ & $50,982^{c}$ & 0,902 \\
\hline PK & $56,178^{a b}$ & $64,932^{\mathrm{a}}$ & $60,837^{\mathrm{a}}$ & $57,492^{a}$ & $53,413^{b}$ & $50,920^{\mathrm{b}}$ & 2,039 \\
\hline NDF & $46,371^{\mathrm{c}}$ & $57,989^{a}$ & $52,838^{a b}$ & $50,726^{\mathrm{b}}$ & $48,996^{b c}$ & $51,099^{b}$ & 1,202 \\
\hline $\mathrm{ADF}$ & $37,247^{\mathrm{c}}$ & $51,002^{a}$ & $45,718^{\mathrm{a}}$ & $44,835^{\mathrm{a}}$ & $44,641^{a b}$ & $40,926^{\mathrm{bc}}$ & 1,707 \\
\hline Selulosa & $50,397^{\mathrm{c}}$ & $60,370^{a}$ & $56,073^{b}$ & $54,767^{b}$ & $53,119^{b c}$ & $51,270^{c}$ & 0,918 \\
\hline Hemiselulosa & 66,417 & 72,034 & 62,606 & 66,063 & 59,230 & 62,377 & 3,427 \\
\hline
\end{tabular}

Keterangan : nilai dengan superskrip yang berbeda pada baris yang sama menunjukkan berbeda nyata $(\mathrm{P}<0,05)$

meskipun tersedia cukup rangka karbon bercabang tanpa diimbangi dengan nutrient precursor lain seperti energi, protein dan mineral dalam jumlah yang cukup dan seimbang maka sintesis protein mikroba tidak akan terjadi secara optimum.

Peningkatan kecernaan zat makanan oleh suplementasi tepung daun ubi kayu disebabkan karena tepung daun ubi kayu mengandung asam amino rantai bercabang. Hasil dekarboksilasi dan deaminasi asam amino rantai bercabang ini akan meng-hasilkan asam lemak rantai bercabang isobutirat, 2 metil butirat dan isovalerat yang merupakan rangka karbon bercabang yang diperlukan untuk sintesis bakteri selulolitik seperti ruminococci dan bacteroides. Hal ini sesuai pendapat (Gorosito et al,1985) bahwa penambahan asam isovalerat, isobutirat,dan 2-metil butirat meningkatkan kecernaan dinding sel dan penggunaan nitrogen.

Suplementasi tepung daun ubi kayu terbaik pada penelitian ini adalah pada level $5 \%$ dari bahan kering. Pada perlakuan ini terjadi peningkatan kecernaan bahan kering, NDF dan ADF masing-masing sebesar $24,09 \%, 25,06 \%$ dan 36,91\% di bandingkan kontrol. Sementara hasil penelitian Zain et al.,(2003) menunjukkan bahwa suplementasi tepung daun ubi kayu terbaik adalah pada level $15 \%$ dari bahan kering pada sabut sawit amoniasi.
Peningkatan kecernaan dinding sel (NDF dan $\mathrm{ADF}$ ) pada penelitian ini membuktikan bahwa penambahan kerangka karbon bercabang ini menguntungkan bakteri selulolitik. Peningkatan kecernaan dinding sel tertinggi didapatkan pada suplementasi $5 \%$ tepung daun ubi kayu yaitu sebesar $25,06 \%$ untuk NDF dan 36,91\% untukADF. Penelitian Zain et al., (2003) juga memperlihatkan bahwa penggunaan tepung daun ubi kayu sebagai sumber asam amino bercabang (valin, leusin, dan isoleusin) pada pakan serat sawit amoniasi mampu memperbaiki kecernaan pakan dan pertumbuhan ternak domba.

\section{Karakteristik cairan rumen}

Hasil pengukuran terhadap parameter karakteistik cairan rumen pada penelitian ini ditampilkan pada Tabel 2. Nilai $\mathrm{pH}$ yang diperoleh pada penelitian ini berkisar antara $6,40-6,72$, hasil analisis statistik menunjukkan suplementasi tepung daun ubi kayu tidak nyata $(\mathrm{P}>0.05)$ mempengaruhi $\mathrm{pH}$ cairan rumen. Nilai ini berada pada kondisi optimal untuk menjamin pertumbuhan dan aktifitas mikroba rumen $(6,3-7,0)$ (Erdman,1988; Orskov dan Ryle 1990).

Apabila $\mathrm{pH}$ rumen dibawah 6,2 maka kehidupan mikroba selulolitik akan terganggu 
Tabel 2.Efek suplementasi beberapa level tepung daun ubi kayu pada daun sawit amoniasi terhadap karakteristik cairan rumen

\begin{tabular}{|c|c|c|c|c|c|c|c|}
\hline \multirow{2}{*}{$\begin{array}{c}\text { Karakteristik } \\
\text { Cairan Rumen }\end{array}$} & \multicolumn{6}{|c|}{ Suplementasi Tepung Daun Ubi Kayu } & \multirow[t]{2}{*}{ SE } \\
\hline & $0 \%$ & $5 \%$ & $10 \%$ & $15 \%$ & $20 \%$ & $25 \%$ & \\
\hline $\mathrm{pH}$ & 6,57 & 6,72 & 6,48 & 6,53 & 6,45 & 6,40 & 0,086 \\
\hline Prod.VFA (mM) & $96,87^{\mathrm{c}}$ & $129,99^{\mathrm{a}}$ & $117,48^{\mathrm{ab}}$ & $108,06^{b}$ & $104,25^{\mathrm{b}}$ & $103,07^{\mathrm{bc}}$ & 4,155 \\
\hline $\mathrm{NH}_{3} \mathrm{~N}(\mathrm{~g} / 100 \mathrm{ml})$ & $11,20^{\mathrm{c}}$ & $15,82^{\mathrm{a}}$ & $14,35^{\mathrm{ab}}$ & $12,60^{\mathrm{b}}$ & $12,74^{\mathrm{b}}$ & $12,32^{\mathrm{bc}}$ & 0,463 \\
\hline
\end{tabular}

Keterangan : nilai dengan superskrip yang berbeda pada baris yang sama menunjukkan berbeda nyata $(P<0,05)$

dan kecernaan serat akan menurun. Nilai $\mathrm{pH}$ yang ideal ini dicapai karena penggunaan saliva buatan yang berfungsi sebagai buffer, sehingga $\mathrm{pH}$ cairan rumen tetap stabil (Orskov dan Ryle 1990), di samping terdapatnya keseimbangan produk fermentasi yaitu VFA dan $\mathrm{NH}_{3}-\mathrm{N}$.

Produksi total VFA pada penelitian ini berkisar antara 96,87- 129,99 mM. Hasil analisis statistik menunjukkan pengaruh perlakuan berbeda yang sangat nyata $(\mathrm{P}<0,01)$ terhadap total VFA. Dari uji DMRT diketahui kosentrasi VFA tertinggi yaitu $129,99 \mathrm{mM}$ diperoleh pada perlakuan $5 \%$ suplementasi tepung daun ubi kayu. Peningkatan level tepung daun ubi kayu menghasilkan peningkatan konsentrasi VFA yang semakin rendah dibanding pada level 5\%, bahkan pada level $20 \%$ dan $25 \%$ konsentrasi VFA setara dengan kontrol ( $0 \%$ tepung daun ubi kayu), hal ini sejalan dengan peningkatan kecernaan zat makanan, dimana kecernaan tertinggi diperoleh pada level 5\% tepung daun ubi kayu, dan level yang lebih tinggi menghasilkan peningkatan kecernaan yang semakin rendah. Hubungan ini mudah dipahami, karena VFA me-rupakan hasil akhir fermentasi karbohidrat oleh mikroba rumen, sehingga peningkatan kecernaan akan menyebabkan peningkatan produk akhirnya yaitu VFA. Davies (1982) menyatakan bahwa peningkatan kadar VFA mencerminkan peningkatan kelarutan kar-bohidrat pakan yang mudah larut. VFA pada ruminansia memiliki peran yang ganda yaitu sebagai sumber energi bagi ternak dan sumber kerangka karbon bagi pertumbuhan protein mikroba (Sutardi et al, 1983).

VFA merupakan unsur dinamis yang jumlahnya tergantung pada fermentabilitas bahan, penyerapan pada dinding rumen dan pemanfaatan oleh mikroba rumen (Warly, et al, 1998). Produksi VFA sangat tergantung pada ragam karbohidrat yang terkandung dalam suatu bahan. Meningkatnya produksi total VFA berarti meningkat pula fermentasi karbohidrat dalam rumen (Baldwin dan Denham, 1979). Produksi total VFA yang diperoleh pada penelitian ini mampu menunjang pertumbuhan dan aktifitas mikroba rumen, sesuai dengan yang dijelaskan oleh Van Soest (1982) total VFA yang dibutuhkan untuk pertumbuhan dan aktifitas mikroba rumen berkisar dari $80-160 \mathrm{mM}$.

Konsentrasi NH3 yang diperoleh pada penelitian ini berkisar $11,20-15,82 \mathrm{mg} / 100 \mathrm{ml}$ cairan rumen. Pada penelitian ini konsentrasi $\mathrm{NH}_{3}-$ $\mathrm{N}$ tertinggi juga diperoleh pada level suplementasi $5 \%$ tepung daun ubi kayu. Tingginya konsentrasi $\mathrm{NH}_{3}-\mathrm{N}$ dan VFA pada perlakuan ini menyebabkan tingginya sintesis protein mikroba, sehingga tinggi pula konsentrasi enzim yang dihasilkan, dan pada akhirnya tercermin dari tingginya angka kecernaan zat-zat makanan.

Secara keseluruhan konsentrasi $\mathrm{NH}_{3}-\mathrm{N}$ yang diperoleh pada penelitian ini telah mencukupi kebutuhan $\mathrm{NH}_{3}-\mathrm{N}$ untuk pertumbuhan dan aktifitas mikroba rumen, sesuai dengan kisaran yang diberikan oleh Satter dan Slyter (1974), Mehrez, et al., (1977) dan Perdok et al., (1988).

\section{KESIMPULAN}

Suplementasi tepung daun ubi kayu pada daun sawit amoniasi yang telah disuplementasi dengan $0,4 \% \mathrm{~S}$ dan $0,27 \% \mathrm{P}$ dapat meningkatkan kecernaan zat-zat makanan secara in-vitro dan mampu mempertahankan karakteristik cairan rumen pada kondisi optimal untuk pertumbuhan mikroba. Level suplementasi daun ubi kayu yang terbaik adalah pada level $5 \%$ dari bahan kering.

\section{DAFTAR PUSTAKA}

Bakrie, B., P. Sitepu., P. Situmorang, P. Pangabean dan C. H. Sirait. 1995. Pemanfaatan kulit buah kakao (Theobroma cacao) sebagai hijauan sumber energi dalam ransum sapi potong. Prosiding Seminar Nasional Sains 
dan Teknologi Peternakan. Balai Penelitian Ternak. Ciawi, Bogor 27-28 September.

Baldwin, R.L. and S.C. Denham. 1979. Quantitative and dynamic aspects of nitrogen metabolism in rumen: a modelling analysis. J.Anim. Sci. 49:1631-1637.

Davies. H.L. 1982. Nutrition, and Growth Manual, Published by Australian Universities International Development Program, Melbourne.

Djajanegara, A.B., Sudaryanto., Winugroho dan A.R.A. Karto. 1999. Potensi produk kebun kelapa sawit untuk pengembangan usaha ternak ruminansia. Laporan APBN 1998/1999. Balai PeneTernak, Puslitbang Peternakan, Bogor.

Erdman, R.A. 1988. Dietary buffering requirement of lactating dairy cows. A. Review. J. Dairy Sci. 71: 3246 .

Gorosito, A. R., J. B. Russel, and P. J. Van Soest. 1985. Effect of C4 and C5 volatile fatty acids on digestion of plant cell wall in vitro. J. Dairy Sci. 68:840.

Mehrez, A.L., E.R. Orskov, and I. Mc. Donald, 1977. Rates of rumen fermentation in relation to rumen ammonia concentration. Brit J. Nutr. 38: 437-443.

Muhtaruddin. 2002. Pengaruh Amoniasi, Hidrolisat Bulu Ayam, Daun Singkong dan Campuran Lisin-Zn-Minyak Lemuru terhadap Penggunaan Pakan pada Ruminansia. Disertasi. Program Pascasarjana Institut Pertanian Bogor, Bogor.

Nurhaita, N. Jamarun, R. Saladin, L Warly dan Mardiati Z. 2007. Efek beberapa metoda pengolahan limbah daun kelapa sawit terhadap kandungan gizi dan kecernaan secara in-vitro. J. Ilmu-Ilmu Pertanian Indonesia no 2: 139-144.

Nurhaita, N. Jamarun, R. Saladin, L Warly dan Mardiati Z, 2008. Efek suplementasi mineral Sulfur dan Phospor pada daun sawit amoniasi terhadap kecernaan zat makanan secara in-vitro dan karakteristik cairan rumen. J. Pengembangan Peternakan Tropis 33(1): 51-58.

Orskov, E.R. and M. Ryle. 1990. Energy Nutrition in Ruminant. Elsevier Appl. Sci. London.
Perdoks, H.B., R.A. Leng., S. H. Bird., G. Habib and $M$. Hovter. 1988. Improving livestock production from straw-based diets. In: E.F. Thompson, F.S. Thompson. Increasing Small Ruminant Productivity in Semi-Arid Areas.

Satter, L.D and L.L. Slyter, 1974. Effect of ammonia concentration on rumen microbial protein production in vitro. $\mathrm{Br}$. J. Nutr. Anim. Sci. 32 : 194-208

Stell, R.G. and J.H. Torrie. 1991. Prinsip dan Prosedur Statistik, Suatu Pendekatan Biometrik. Edisi 2. Alih Bahasa B. Sumantri. PT. Gramedia Pustaka Utama, Jakarta.

Sutardi, T, N.A. Sigit dan Toharmat. 1983. Standardisasi Mutu Protein Makanan Ruminansia Berdasarkan Parameter Metabolismenya oleh Mikroba Rumen. Fakultas Peternakan IPB Bekerjasama dengan Direktur Pembinaan dan Pengabdian pada Masyarakat Depdikbud. Jakarta.

Tilley, J.M. A and Terry. 1963. A two stage technique for in-vitro digestion of forage crops. J. Brit. Grassland Soc. 18 (2):104111.

Van Soest, P.J. 1982. Nutritional Ecology of Ruminant. O\&B Books Inc., Virginia.

Warly, L., A. Kamaruddin, Hermon, R.W.S Ningrat dan Elihasridas. 1998. Pemanfaatan Hasil Ikutan AgroIndustri sebagai Bahan Makanan Ternak Ruminansia (evaluasi secara in-vivo). Laporan Penelitian Hibah Bersaing V/2 Perguruan Tinggi Tahun Anggaran 1997/1998. Fakultas Peternakan Universitas Andalas. Padang.

Zain, M. 1999. Substitusi Rumput dengan Sabut Sawit dalam Ransum Pertumbuhan Domba: Pengaruh Amoniasi, Defaunasi dan Suplementasi Analog Hidroksi Methionin serta Asam Amino Bercabang. Disertasi Program Pascasarjana Institut Pertanian Bogor, Bogor.

Zain, M., Elihasridas dan Dj. Mangunwidjaya. 2003. Efek suplementasi daun ubi kayu terhadap kecernaan dan fermentabilitas (in-vitro) ransum berpakan serat sawit amoniasi urea. J. Andalas No. 41: 6471. 